\title{
A Unique Representation of Female Urinary Catheter in Ancient Roman Art
}

Antik Roma Sanatında Kadın Üriner Kateterinin Eşsiz Bir Temsili

\author{
(1) Ekrem Güner1', (1) Şebnem İzmir Güner², (1) 0sman Özdemir1 \\ ${ }^{1}$ Bakırköy Dr. Sadi Konuk Training and Research Hospital, Clinic of Urology, İstanbul, Turkiye \\ ${ }^{2}$ Kolan International Hospital, Clinic of Hematology and Bone Marrow Transplantation, istanbul, Turkiye
}

\section{Introduction}

Diseases and maladies, for which the man has looked for remedy all the time, spread with the beginning of mankind. Inadequate urine drainage and associated serious issues are the most common urological problems (1).

Various urinary catheters have been found among the medical and surgical tools during the archeological diggings where the Ancient Greek and Roman Civilizations took place. Some of the writings of antic age physicians reached today prove that these catheters had been used particularly during the Roman Empire. Celsus, the Roman physician of the ancient time (25 B.C.-50 A.D.), asserted that trouble in urinating, affecting both sexes, might develop due to old age or keeping urine as a bad habit for which bronze tubes were used to discharge urine. He not only described the urinary catheters very well, but also explained the length of the male and female bladder catheters by utilising the rule of thumb. He defined that the catheters should have been of different and ergonomic size for each body and sex, with curved and longer ones to be used just for males, and should have also been chosen with utmost care for the patient (2).

Another antic Roman physician, Galen (129-216 A.D.) explained how they drained the bladder by inserting an S-shaped catheter thorough the urethra. On the other hand, Paul (625-690 A.D.), a Byzantine physician, explained the usage of catheter and draining the bladder. He further detailed how to choose a catheter according to height, weight and sex of the patient. He also described how the catheter should be pushed into the urethra while the patient had a proper sitting position and then how the urine was discharged through the catheter (3). By explaining the necessity of pushing stones causing urinary retention with a proper catheter into the bladder, Soranus of Ephesus (98-138 A.D.) well described that catheters could also be used for the treatment of occlusive urethral stones or bladder stones (4).

Since bronze is a brittle metal, bronze catheters are rarely discovered in archeological sites. Most of these bronze catheters were found to be curled and S-shaped, rarely short, straight or slightly curved $(5,6,7,8)$. Besides these bronze catheters, a highly rare urethral catheter, made up of bone belonging to the Private Museum of Haluk Perk (HPM) in İstanbul exhibited with the inventory no. of 13342 and discovered in an unknown findspot in Anatolia was one of the most outstanding antic catheters (9) (Figure 1). Of being straight and $125.4 \mathrm{~mm}$ in length, the catheter origination from Roman period proves that it was manufactured for females. The antic catheter made up of bone has similarities with the modern ones in terms of physical appearance and it is assumed that it was specially manufactured with a closed tip and holes on the sides in order to push forward.

\section{Conclusion}

As mentioned by the antic age physicians, longer and S-shaped and curled urinary catheters made up of bronze seem more compatible for male urethral anatomy. On the other hand, the aforementioned short and straight catheter made up of bone is suitable to female urethral anatomy. Since there is not a known another urinary catheter made up of bone originating from

Correspondence: Osman Özdemir MD, Bakırköy Dr. Sadi Konuk Training and Research Hospital, Clinic of Urology, İstanbul, Turkiye Phone: +90 5057070308 E-mail: ozdemirosman2@gmail.com ORCID-ID: orcid.org/0000-0003-0375-8282

Received: 24.03.2019

Accepted: 26.03 .2019

Cite this article as: Güner E, Güner Şi, Özdemir 0. A Unique Representation of Female Urinary Catheter in Ancient Roman Art. J Urol Surg 2019;6(2):172-173.

๑Copyright 2019 by the Association of Urological Surgery / Journal of Urological Surgery published by Galenos Publishing House. 


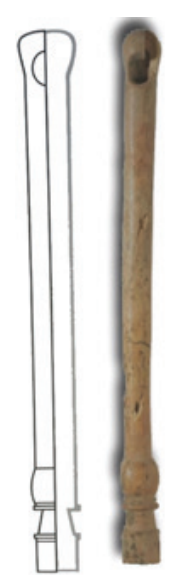

Figure 1. Straight urinary catheter with side hole and blocked tip, made up of bone and from Antic Roman period

Ancient Greek and Roman period, the catheter being exhibited at the HPM stands out as unique and unrivaled.

Keywords: Ancient catheters, Urinary catheters, Bladder catheters, Female urinary cathaters, Roman Art

Anahtar Kelimeler: Antik kateterler, Üriner kateterler, Mesane kateterleri, Kadın üriner kateterleri, Roma Sanatı

\section{Ethics}

Peer-review: Internally peer-reviewed.

\section{Authorship Contributions}

Surgical and Medical Practices: E.G., S.I.G., O.Ö., Concept: E.G., S.i.G., 0.0̈., Design: E.G., S.I.G., O.Ö., Data Collection and/or
Processing: E.G., S.I.G., O.Ö., Analysis or Interpretation: E.G., O.Ö., Literature Research: E.G., S.I.G., O.Ö., Writing: E.G., S.I.G., 0.Ö.

Conflict of Interest: No conflict of interest was declared by the authors.

Financial Disclosure: The authors declared that this study received no financial support.

\section{References}

1. Max Neuburger, David Riesman, The Early History of Urology, Bulletin of the Medical Library Association 25, 1937;147-165.

2. Celsus, Aulus Cornelius. "Book VII, Chapter XXVI: Of the operation necessary in a suppression of urine, and lithotomy." Collier GF: A translation of the eight books of Aul. Corn. Celsus on medicine, 2nd ed., London: Simpkin and Marshall 1831:306-314.

3. Francis Adams The Seven Books of Paulus Aegineta: Translated with a Commentary Embracing a Complete View of The Knowledge Possessed by the Greeks, Romans and the Arabians on All Subjects Connected with Medicine and surgery, Sydenham Soc., 3 vols, London, 1844-1847.

4. Soranus, Gynecology Translated by Owsei Temkin, Baltimore, The John Hopkins Univercity Press 1956.

5. Milne, SJ Surgical instruments in Greek and Roman Times, Chicago, Ares Publications. 1976.

6. Simpson G. Roman Weapons, Tools, Bronze Equipment and Brooches from Neuss- Novaesium Excavations 1955-1972, BARIntSer 862, Oxford, 2000.

7. Baykan D, Allianoi Tıp Aletleri, Türk Eskiçağ Bilimleri Enstitüsü, İstanbul 2012, pp134-202.

8. Uzel İ. Anadolu'da Bulunan Antik Tıp Aletleri, Türk Tarih Kurumu Basımevi, p.219, Ankara 2000.

9. Perk H, Anatolia Ancient Period Medicine Instruments, İstanbul 2012, pp 111. 